\title{
Article
}

\section{Sustainable Entrepreneurship in the 2030 Horizon}

\author{
Fernando Crecente *(D), María Sarabia (D) and María Teresa del Val (D) \\ Department of Economics and Business Management, University of Alcalá, 28801 Alcalá de Henares, Spain; \\ maria.sarabia@uah.es (M.S.); mteresa.val@uah.es (M.T.d.V.) \\ * Correspondence: fernando.crecente@uah.es
}

Citation: Crecente, F.; Sarabia, M.; del Val, M.T. Sustainable Entrepreneurship in the 2030 Horizon Sustainability 2021, 13, 909. https:// doi.org/10.3390/su13020909

Received: 29 December 2020

Accepted: 14 January 2021

Published: 18 January 2021

Publisher's Note: MDPI stays neutral with regard to jurisdictional claims in published maps and institutional affiliations.

\begin{abstract}
Background: this paper analyzes the relationship between entrepreneurship and sustainability following the worldwide reference of the 2030 Sustainable Development Goals (SDGs) framework set by the United Nations. Nowadays, these SDGs are the inspiration for many types of entrepreneurship that combine value creation with conservation and social protection. (2) Methods: using the indicators provided by Eurostat in its section called "Sustainable development indicators", we have developed a dataset of 21 variables applied to the European Union (EU27) for the period 2013-2017. (3) Results: the results hold that these SDGs have favored a climate of change in the European economies towards more responsible behavior on the part of society, institutions, and their business fabric, creating new sustainable entrepreneurship. (4) Conclusions: the promotion of the SDGs has contributed to increasing the rate of entrepreneurial activity in the period 2013-2017.
\end{abstract}

Keywords: entrepreneurship; sustainability; sustainable development goals (SDGs); sustainable entrepreneurship goals (SEGs)

\section{Introduction}

We are celebrating the 75th anniversary of the United Nations and the 5th anniversary of the adoption of the Sustainable Development Goals. At the same time, we are experiencing a pandemic that is transforming our economies and societies in an unexplored way. In this context, the Sustainable Development Goals (SDGs) are the inspiration for many types of entrepreneurship that combine value creation with conservation and social protection. In 2030, these SDGs also will mark the way to create new ventures that deserve to be investigated and promoted. Some authors define the concept of eco-entrepreneur [1] and other authors [2] define sustainable entrepreneurship as a model of economic and social behavior, opening the doors to sustainability in entrepreneurship [3-5].

Sustainable entrepreneurship represents the link between business the creation process and holistic well-being (social, economic, health or environmental). Circular business models focused on reducing the negative impacts on society, the environment and the efficient use of goods and services, giving rise to entrepreneurship and intrapreneurship projects within the so-called green economy [1].

The European Environment Agency (EEA) [6] applies the circular economy concept to "all kinds of natural resources, including biotic and abiotic materials, water and land. Eco-design, repair, reuse, refurbishment, remanufacture, product sharing, waste prevention and waste recycling are all important in the circular economy." That represents a colored fan of different sustainable economies such as blue one (water) and green one (land).

Health and well-being constitute the third goal of the sustainable development 2030 agenda and pose a global challenges because, firstly, they assume a transformation in ways of understanding health — through the prevention of disease with a healthy diet and physical exercise-and second, because they represent a new way of caring for health not as an option, but as both an individual and a social responsibility. Although obesity is one of the diseases with the greatest impact in the 21st century, in Spain it has been possible to reduce the overweight figures by three percentage points, especially in boys and girls 
between 6 and 9 years old (from 44.5\% to 41.3\%) from 2011 to 2015, although this is still not enough to reach this global goal.

For this, the role of companies and the new organic enterprise-in defense of health care as a preventive measure for chronic diseases-is crucial. On the one hand, a business transformation is taking place because it forces companies to join in constant innovation to obtain the best products in even healthier conditions; and on the other, a generation of health-related enterprises (organic textiles, organic food, free cosmetics, etc.) is arising that guarantee a clear economic function together with a social one. Hence the importance of this type of enterprise, because it is not limited only to products in the shopping cart, but also involves other related entrepreneurial sectors, such as catering, restoration or vending.

The new business models called for by the circular economy, focused on reducing negative impacts on society, the environment and the efficient use of goods and services, give rise to entrepreneurship and intrapreneurship projects within the so-called green economy [1]. The circular economy, green economy and bioeconomy are three linked sustainability concepts [7]. Under the circular economy, new business opportunities arise from recycling. In the industrial sector, approximately more than $50 \%$ of the costs in these companies are associated with the consumption of raw materials, which include extraction, importation and transport of these [8]. Likewise, awareness must be raised towards innovative production models that promote the use of non-polluting energy, increasing the useful life of products or their shared consumption. That is, the philosophy of zero waste also known as the 5Rs: refuse, reduce, reuse, recycle and rot. The paper of D'amato et al. [7] synthetizes recent literature about business models under a circular process $[9,10]$ and the circular bioeconomy (CEBE) [11]. In the case of the bioeconomy, some authors hold that the business process uses biotechnology developing agro-ecological land-use techniques [12,13].

This same concern occurs when the oceans, rivers and the rest of the water resources are considered, since they absorb more than two-thirds of the carbon dioxide produced by industries, thus helping to cushion the impact of global warming. All types of project or action related to access to quality water, as well as the maintenance of marine fauna, are called blue entrepreneurship. One initiative that brings together the two types of sustainable entrepreneurship, due to its impact on the media, is related to the consumption of plastic and the treatment of garbage.

In this way, circular entrepreneurship can be distinguished between organic entrepreneurship and sustainable entrepreneurship (green and blue). Some authors explain how farming illustrates the long-term benefits of organic food and healthy lifestyles $[14,15]$ (see Figure 1).

Education allows the acquisition of values, knowledge, and skills to access other higher educational levels or to access the job market, either to work for someone else or independently. Therefore, access to education is a right that must be guaranteed at all stages of life and is related to SDG 4 and SDG 8 (see Figure 1). In this sense, entrepreneurship is linked to education through educational processes (tacit and explicit knowledge) which provide the passion for creating and implementing new business ideas [16]. Other authors relate entrepreneurial process to educational programs such as, for example, military service [17]. Military education develops values such as loyalty, effort, and work that is well done, and entrepreneurship is a career path for military veterans $[18,19]$. According to Ferreira et al. [20], entrepreneurial spirit or motivation is based on five groups of entrepreneurial theories: (1) the knowledge diffusion theory of entrepreneurship, (2) the theory of creation and networks, (3) decision-making theory, (4) job specialization, (5) entrepreneurship in the informal sector of the economy. 


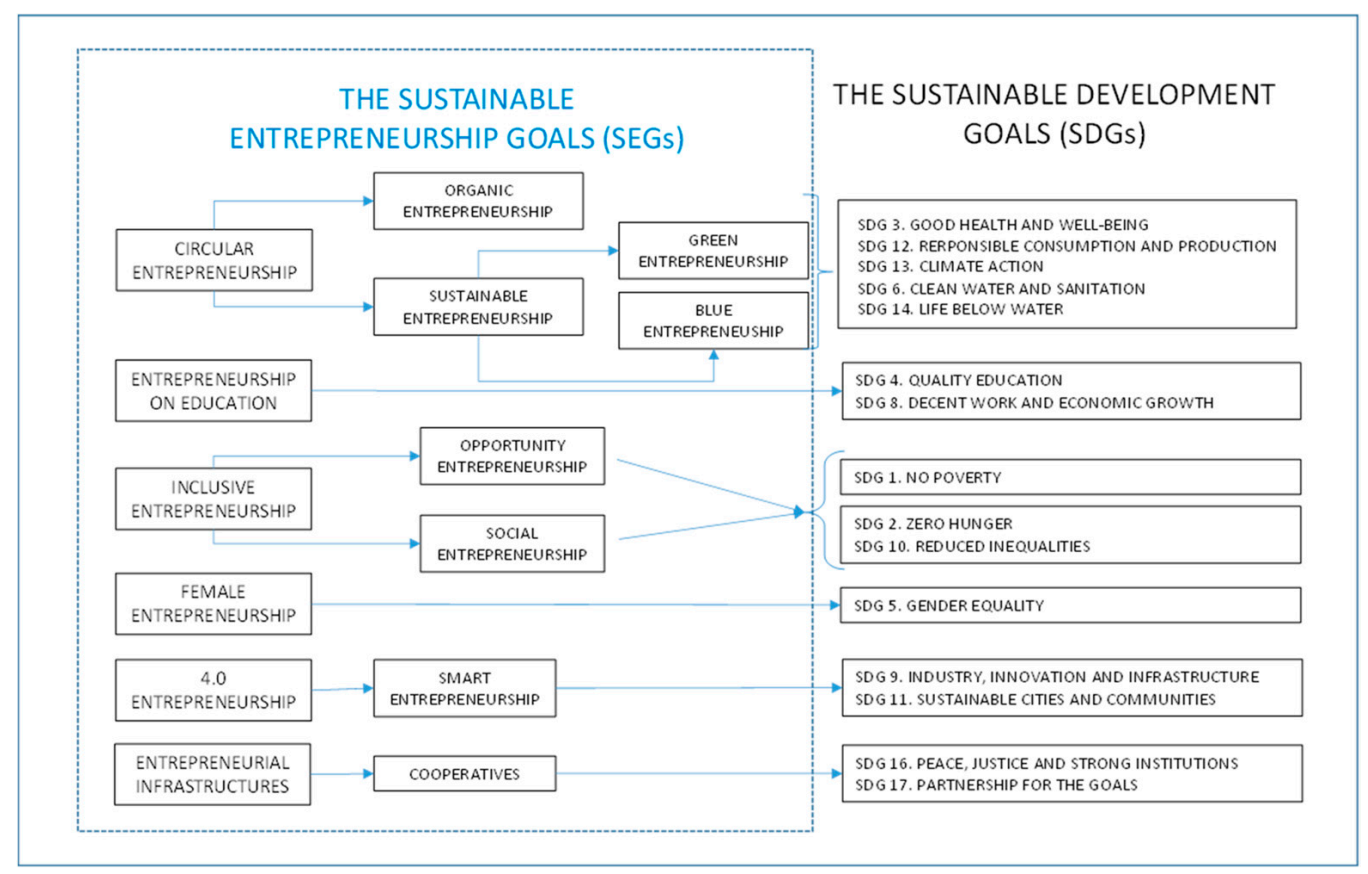

Figure 1. Relationship between sustainable entrepreneurship goals and the Sustainable Development Goals (source: own work).

Inclusive entrepreneurships create opportunities through improving the communities where they operate. Their founders fight poverty, hunger, gender, sex, and race inequality creating businesses that develop social and economic value. The motivation of these entrepreneurs is to provide equal opportunities for those suffering disability, being in a minority, or any other form of exclusion through employment [21]. In this way, cooperatives are presented as a type of partnership developed in the case of inclusive communities. This sharing economy is developed as a community-based economy with different forms of interaction: contractual or non-contractual, hierarchical, or non-hierarchical or profit or non-profit. Nowadays, these entrepreneurships based on well-being, justice, rights, and equality are creating a new way of doing business focusing on different industries (organic food, crafts, etc.).

Female entrepreneurship is studied around the world. Some studies hold that women entrepreneurs present individual characteristics such as self-motivation, fear of failure and personal satisfaction more than men [22-25]. Other studies demonstrate that female entrepreneurship tends to create small businesses and to grow less than in the case of male entrepreneurs [26,27].

The SDG 11 of the United Nations, sustainable cities and communities, is proposed as right of all urban communities around the world. Nowadays, urban life represents more than half of the population and in 2050 this will be two-thirds of all humanity. In this sense, smart cities discover new technological opportunities for improving the community's way of life and focusing on new entrepreneurial opportunities [28,29]. Following Giffinger et al. [30], the smart city represents different perspectives: smart people, smart governance and smart economy, smart mobility, smart environment, and smart living [31]. This approach is a concept of smart sustainability which is being developed by inclusive entrepreneurs aiming to promote social and economic benefits for their communities [32].

There are new forms of sustainable entrepreneurship aimed at the care and protection of people and their environments: (1) circular entrepreneurship, identifying organic (on health and well-being), green (action for climate and ecosystems) and blue (clean water and underwater life); (2) inclusive entrepreneurship, defining business project focus on the promotion of equality and social justice though education; (3) female entrepreneurship; and (4) smart entrepreneurship 4.0. This research provides a framework for explaining 
how these sustainable entrepreneurships are related to political actions such as the SDGs. Our European approach is a first approximation to these worldwide and sustainable entrepreneurial behaviors.

The implementation of new sustainable economic-productive models associated with the primary sector (organic entrepreneurship) will be replicated in other sectors, especially in the food industry and its derivatives (food processing, packaging, etc.). This also highlights the adaptation of principles of circular economy in production processes as a variable that contributes to the generation of an enterprise committed to society and its environment. The new business models called for by the circular economy, focus on reducing negative impacts on society, the environment and the efficient use of goods and services, and give rise to entrepreneurship and intrapreneurship projects within the so-called economy green. In both types of enterprise, the greater presence of women entrepreneurs is significant, helping within an inclusive enterprise to reduce gender differences. It will also generate a multitude of business opportunities for emerging sectors, allowing stable growth for the economies that have these entrepreneurs as well as a high potential for impact and social transformation.

\section{Materials and Methods}

The aim of this research is to analyze the variation that has occurred in entrepreneurial activity in European regions since the creation of the SDGs, as well as to analyze the potential effect that these SDGs have on the entrepreneurial activity rate. The analysis considers the birth of new business initiatives as an expression to take advantage of the new opportunities generated by the environment of the SDGs. All the actions that must be put in place, jointly by companies, institutions, and social agents to achieve responsible consumption, careful with the environment and considering the vital needs of groups at risk of exclusion, become a source of ideas and resources for entrepreneurs to take advantage of this opportunity with their capabilities. Therefore, the main hypothesis to be tested is the following: The promotion of the SDGs has contributed to increasing the rate of entrepreneurial activity in European regions in the period 2013-2017.

\subsection{Sample and Variables}

We have used for this study the number of companies created in a region as an approximation of entrepreneurial activity. Although there are reports such as the Global Entrepreneurship Monitor (GEM) and its total entrepreneurial activity (TEA), we have decided to consider the Eurostat harmonized company demographic records for the measurement of entrepreneurial activity in a specific year compared to the total number of companies active in that region in the same year.

The objective of these harmonized demographic records is to provide aggregate information regarding the population of companies established in a national territory according to aspects related to business dynamism and applying a methodology agreed upon within the scope of the European Union (Regulation (EC) No. 295/2008 of the European Parliament and of the Council of 11 March 2008). The starting populations are made up of the set of units that enter, stay, and leave the system. In this way, this methodology allows us to obtain indicators at the national level, and thus have a comparable statistical base for the countries of the European Union.

Specifically, two flows of companies are considered: (a) stock of companies: the set of units active during all or part of the year. This includes companies that remain active at the end of the year, plus those that have temporarily ceased their activities throughout the year; and (b) new companies: a set of units that throughout the year have created a combination of new production factors. They are not linked to other companies previously created. The entrepreneurship rate (NE) is defined as follows:

$$
N E_{t, j}=\frac{B_{t, j}}{S_{t, j}}
$$


where $B$ is the rate of companies born in a certain region $(j)$ and a certain period $(t)$ and $S$ is the stock of active companies in a certain region $(j)$ and a certain period $(t)$. For example, France created 302,580 companies in 2013 and its total number of active companies was $3,181,072$ in this period, which represents a rate of creation of new companies of $9.51 \%$.

On the other hand, for the consideration of the different dimensions that make up the SDGs, the information provided by Eurostat in its section called "Sustainable development indicators" has been used. In this section, a battery of more than 100 indicators distributed among the 17 SDGs is supplied.

When analyzing data availability, for some variables there were no records for all European countries. Or, if there were records, there were many gaps in the information over the years. For this reason, it was decided to work with the time horizon 2013 to 2017, which implies a period of dissemination of five years for the SDGs. In the case of time series in which there are some missing data, the median value of the region in these variables was used as a substitute element. All this results in a robust series of 27 European countries: AT, BE, BG, CY, CZ, DE, DK, EE, El, ES, FI, FR, HR, HU, IE, IT, LT, LU, LV, MT, NL, PL, PT, RO, SE, SI, SK and UK.

\subsection{Model}

First, a matrix is presented that relates the ratio of new company births at the beginning of 2013 to the variation rate of new company creation in the 2013-2017 period. This matrix allows us to see the degree of convergence-divergence of the European countries analyzed in their business dynamics.

On the other hand, given the large number of variables that are considered in the different SDGs, the variables that are most closely related to the economic-business environment have been selected for each of the 17 pillars (see Figure 1), excluding those variables of a more political or technical nature. with less impact on business activity. For each of the variables for the purposes of the analysis, the mediated value of the variable over the period considered has been considered. Once this set of variables has been considered in each SDG, they have been used to explain the variation rate in the period. In this way, the variables that statistically result in a significance level greater than $90 \%$ have been selected for each SDG.

$$
\begin{aligned}
& \text { Variation } N E_{2013-2017}=\alpha+V 1 \_S D G 1_{2013 / 17}+V 2 \_S D G 1_{2013 / 17}+\ldots+\varepsilon_{2013 / 17} \\
& \text { Variation } N E_{2013-2017}=\alpha+V 1 \_S D G 2_{2013 / 17}+V 2 \_S D G 2_{2013 / 17}+\ldots+\varepsilon_{2013 / 17} \\
& \text { Variation } N E_{2013-2017}=\alpha+V 1 \_S D G 17_{2013 / 17}+V 2 \_S D G 17_{2013 / 17}+\ldots+\varepsilon_{2013 / 17}
\end{aligned}
$$

In this way, a first reduction in the number of variables associated with the SDGs that can influence entrepreneurial activity is achieved. However, to try to identify the most relevant elements, a factorial correspondence analysis is proposed with the set of individual variables that are significant for the creation of companies. Varimax rotation has been established for a better interpretation of the factors, which performs an orthogonal rotation of the factorial axes. Those factors with an eigenvalue in the correlation matrix greater than one will be obtained. The objective of this rotation is to ensure that the correlation of each of the variables is closest to one with only one of the factors and close to zero with all the others. The Bartlett test is used as a verification contrast. Finally, a regression model is proposed using the factors related to the creation of companies, to determine what types of entrepreneurship could have been enhanced.

$$
\text { Variation } N E_{2013-2017}=\alpha+\text { Factor } 1+\text { Factor } 2+\ldots+\varepsilon_{t}
$$

\section{Results}

Firstly, the set of variables on business dynamics among the different European regions have been analyzed. The variable "growth/average decrease in the number of companies created" compared to the total number of active companies in the 2013-2017 period has 
been used as a variable of approximation of entrepreneurship. This metric is also an approximation of the economic growth of the regions, given the high correlation between GDPs per capita and the evolution of the number of companies present in the regions. That is, the regions with the greatest number of dynamisms in the creation of companies are presumed to be those with the greatest wealth.

In 2012, the SDGs were announced to confront the serious global economic crisis that began in 2007, which may lead to the emergence of new business opportunities and the consolidation of existing companies, that is, a process of convergence and business reconstruction between European regions (see Figure 2). Using a convergence-divergence matrix, which relates the ratio of new company births at the beginning of 2013 (NE2013) with the variation rate of new company creation in the 2013-2017 period (Q13-17), it is possible to know the degree of rapprochement or polarity of different European countries in their business dynamics. For that reason, the average values of the set of countries in both variables are taken as a reference, being the European average of company creation at the beginning of 2013 (NE2013) of 10.3 companies created for every 100 existing companies and the average growth rate of companies of 1.55\% in the period 2013-2017 (Q13-17). Thus, those countries that started from company creation rates below the European average but have had growth in the period above the average converge positively, while other countries that started from company creation rates above the average have growth in the aboveaverage period that diverges. This matrix allows a first approach to the phenomenon of entrepreneurship in countries and to determine those countries with the greatest potential or commitment to the figure of entrepreneurship and business creation in their regions.

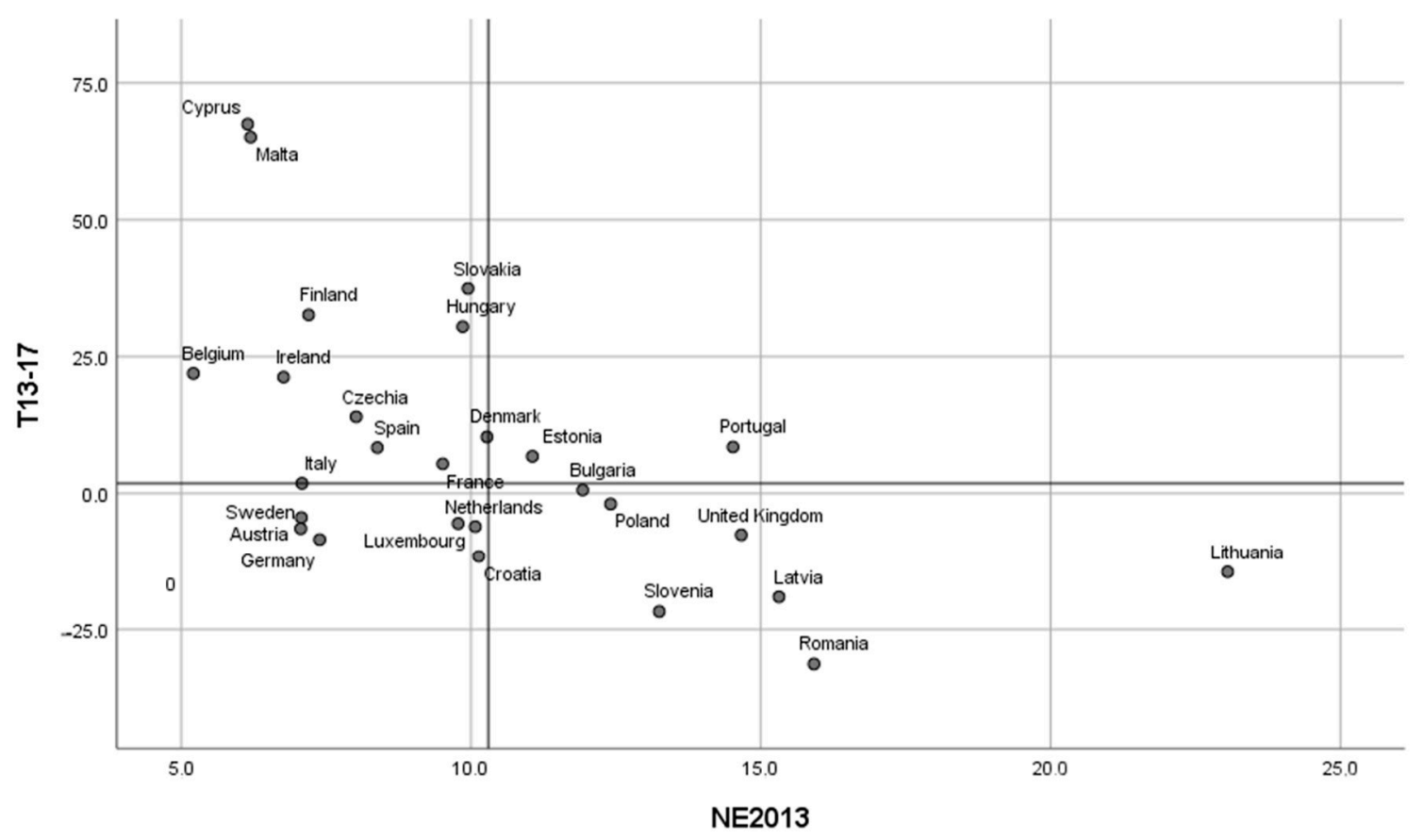

Figure 2. European convergence-divergence in business creation (source: own work).

The appearance of the SDGs has favored a climate of change in the European economies towards more responsible behavior on the part of society, institutions, and their business fabric. This increased awareness has favored the generation of business opportunities and entrepreneurship. The involvement and support of institutions at all levels is necessary to develop entrepreneurial initiatives focusing on responsible and sustainable elements. Public policies, such as the deregulation of sectors, simplification of administrative procedures, policies that directly influence the risk-benefit ratio (financial support, guarantee systems, etc.) and bonuses for betting on the circular economy in production processes, allow the demand for entrepreneurial activity in a country to expand. 
Among the convergent regions, these are nuanced among those that have a lower business density of births at the beginning of the period (NE2013: Business' creation index 2013) but have had greater entrepreneurial dynamism in the period (T13-17: Variation of new businesses growth index), that is, they are the regions prone to take advantage of the opportunities of the new environment. Among them are the countries of Cyprus, Malta, Finland, Ireland, and Spain. By contrast, the regions that have a higher density of business creation at the beginning of the period but have seen their rate of entrepreneurship reduced during the period, are Romania, Latvia, Lithuania, Poland, and United Kingdom.

On the other hand, within the divergent regions it is also possible to distinguish two types of behavior. On the one hand, the regions of Sweden, Germany and Austria show the lowest business density at the beginning of the crisis and have seen a reduction in the number of new ventures, that is, they are in the process of readjusting their production units. By contrast, there are regions that have a higher business density at the beginning of the period and have continued to bet on entrepreneurship, such as the regions of Portugal and Estonia.

Thus, during the analyzed period there has been a process of regional adjustment or convergence, so that the regions that had less business creation have seen their initiatives grow in the period considered, while they started from a more favorable situation in terms of business dynamism, their rate of business creation has been reduced. That is, there has been a rapprochement between the different European regions, converging between them in a slow process of economic and business recovery.

Once the existence of dynamism in the creation of companies in European countries has been made clear, it is a question of examining which of the determining variables of the SDGs statistically influences this variation. Table 1 presents the variables that within each SDG are significant to explain the variation in the creation of companies in the European regions. For example, in the case of SDG 9 (Industry, innovation and infrastructure) the variables that comprise it are: share of rail and inland waterways; share of busses and trains in total passenger; research and development (R\&D) personnel; Patent applications to the European Patent Office; gross domestic expenditure on R\&D; employment in high- and medium-high technology manufacturing and knowledge-intensive services; and average $\mathrm{CO} 2$ emissions per $\mathrm{km}$ from new passenger cars. Of this set of variables, the only one that is significant for explaining the variation in business creation is the rate of the population employed in the technology sectors. This relationship is positive. For the rest of the SDGs, it can be seen that the higher index of the population at risk of poverty or the greater disparity in terms of income of the inhabitants of a smaller region create the dynamic of business creation. On the other hand, the higher the obesity index in the regions or the higher the ratio of use of circular materials, the greater the dynamics in the creation of companies in the regions.

Table 1. Significant variables of the different Sustainable Development Goals (SDGs) to explain business creation ${ }^{1}$.

\begin{tabular}{cclcccc}
\hline \multirow{2}{*}{ SDG } & & Significant Variables & Coef. Stand. & t & Sig. & Reta \\
\cline { 3 - 6 } No poverty & Social Transfer & $\begin{array}{l}\text { People at risk of income poverty after } \\
\text { social transfers }\end{array}$ & -0.618 & -2.943 & 0.007 & 0.288 \\
\hline Zero Hunger & Ammonia & Ammonia emissions from agriculture & 0.534 & 2.681 & 0.014 & 0.31 \\
\hline Good Health and well-being & Obesity & $\begin{array}{l}\text { Obesity rate by body mass } \\
\text { index_obesity }\end{array}$ & 0.453 & 2.239 & 0.036 & 0.315 \\
\hline Quality education & Employment & $\begin{array}{l}\text { Employment rates of recent graduates } \\
\text { by sex }\end{array}$ & 0.824 & 1.741 & 0.096 & 0.172 \\
\hline Gender Equality & Inactive & $\begin{array}{l}\text { Inactive population due to caring } \\
\text { responsibilities by sex }\end{array}$ & 0.377 & 1.725 & 0.099 & 0.289 \\
\hline
\end{tabular}


Table 1. Cont.

\begin{tabular}{|c|c|c|c|c|c|c|}
\hline \multirow{2}{*}{ SDG } & & \multirow{2}{*}{ Significant Variables } & Coef. Stand. & \multirow{2}{*}{$\mathbf{t}$} & \multirow{2}{*}{ Sig. } & \multirow{2}{*}{$\mathbf{R}^{2}$} \\
\hline & & & Beta & & & \\
\hline \multirow{2}{*}{ Clean water-sanitation } & Hygene & $\begin{array}{l}\text { Population having neither a bath, nor } \\
\text { a shower, nor indoor flushing toilet in } \\
\text { their household }\end{array}$ & -0.537 & -3.459 & 0.002 & \multirow{2}{*}{0.448} \\
\hline & Wastewater & $\begin{array}{l}\text { Population connected to at least } \\
\text { secondary wastewater treatment }\end{array}$ & -0.531 & -3.423 & 0.002 & \\
\hline \multirow{2}{*}{ Affordable and clean energy } & Dependency & Energy import dependency by products & 0.381 & 1.974 & 0.062 & \multirow{2}{*}{0.485} \\
\hline & Gas & $\begin{array}{l}\text { Greenhouse gas emissions intensity of } \\
\text { energy consumption }\end{array}$ & -0.521 & -2.815 & 0.011 & \\
\hline $\begin{array}{l}\text { Industry, Innovation } \\
\text { and infraestructure }\end{array}$ & Tecnology & $\begin{array}{l}\text { Employment in high- and } \\
\text { medium-high technology } \\
\text { manufacturing and } \\
\text { knowledge-intensive services }\end{array}$ & 0.557 & 1.793 & 0.089 & 0.354 \\
\hline Reduced Inequalities & Income & Income distribution & -1.873 & -1.728 & 0.1 & 0.354 \\
\hline \multirow{5}{*}{$\begin{array}{l}\text { Sustainable cities } \\
\text { and communities }\end{array}$} & Transport & $\begin{array}{l}\text { Share of busses and trains in total } \\
\text { passenger transport }\end{array}$ & 0.489 & 3.939 & 0.001 & \multirow{5}{*}{0.73} \\
\hline & Settlement & Settlement area per capita & 0.247 & 1.793 & 0.087 & \\
\hline & Recycling & $\begin{array}{l}\text { Recycling rate of waste excluding } \\
\text { major mineral wastes }\end{array}$ & -0.581 & -4.609 & 0 & \\
\hline & Overcrowding & Overcrowding rate by poverty status & 0.999 & -6.17 & 0 & \\
\hline & Pollution & $\begin{array}{l}\text { Exposure to air pollution by } \\
\text { particulate matte }\end{array}$ & 0.425 & 2.457 & 0.023 & \\
\hline \multirow{4}{*}{$\begin{array}{l}\text { Responsable consumption } \\
\text { and prodution }\end{array}$} & $\mathrm{DMC}$ & $\begin{array}{l}\text { Resource productivity and domestic } \\
\text { material consumption }\end{array}$ & 0.984 & 2.465 & 0.023 & \multirow{4}{*}{0.529} \\
\hline & Circular & Circular material use rate & 0.692 & 2.714 & 0.014 & \\
\hline & PPS & $\begin{array}{l}\text { Energy productivity purchasing } \\
\text { power standard }\end{array}$ & -0.666 & -3.284 & 0.004 & \\
\hline & Renewable & $\begin{array}{l}\text { Share of renewable energy in gross } \\
\text { final energy consumption }\end{array}$ & -0.417 & -2.33 & 0.031 & \\
\hline Life on land & Primary & $\begin{array}{l}\text { Primary energy consumption. } \\
\text { Million tonnes of oil. }\end{array}$ & -1.273 & -1.993 & 0.06 & 0.298 \\
\hline
\end{tabular}

A factor analysis is proposed to reduce and group the 21 selected variables (Table 2); $80.11 \%$ of the total variance is captured using five significant factors. Thus, factor 1 includes variables associated with the distribution of income, the unemployment of recent graduates, the obesity rate, access to technologies and the population's ability to access water. All these are factors linked to social conditions and the infrastructure endowment of the regions. Factor 2 groups the variables related to the use of renewable energies and the pollution generated by the primary sector. Factor 3 considers the density of urban areas and the risk of poverty (factors of social exclusion). Factor 4 groups the variables that describe the SDG related to sustainable cities and communities, which indicates a factor associated with the environment or occupational habitat. Finally, factor 5 considers variables related to the circular economy, access to water resources, dependence on energy resources and the inactive population due to attending to family responsibilities, which considers factors related to gender diversity and the green economy. 
Table 2. Explanatory factors of the SDGs with the ability to influence entrepreneurship ${ }^{1}$.

\begin{tabular}{|c|c|c|c|c|c|}
\hline Variables & Factor 1 & Factor 2 & Factor 3 & Factor 4 & Factor 5 \\
\hline Income & -0.932 & & & & \\
\hline Tecnology & 0.896 & & & & \\
\hline Employment & 0.827 & & & & \\
\hline Obesity & 0.690 & & & & \\
\hline Hygene & -0.601 & & & & \\
\hline Renewable & & 0.916 & & & \\
\hline Gas & & 0.836 & & & \\
\hline Primary & & 0.802 & & & \\
\hline Ammonia & & -0.602 & & & \\
\hline Social Transfer & & & 0.923 & & \\
\hline Settlement & & & 0.849 & & \\
\hline Overcrowding & & & & 0.807 & \\
\hline Transport & & & & 0.785 & \\
\hline Pollution & & & & 0.596 & \\
\hline DMC & & & & -0.596 & \\
\hline Circular & & & & & 0.750 \\
\hline Wastewater & & & & & -0.671 \\
\hline Inactive & & & & & 0.580 \\
\hline Dependency & & & & & 0.522 \\
\hline \% Variance & 23.69 & 18.73 & 13.69 & 13.27 & 10.73 \\
\hline$\%$ Acumulated Variance & 23.69 & 42.42 & 56.11 & 69.38 & 80.11 \\
\hline
\end{tabular}

${ }^{1}$ Source: own work. Bartlett's Test Sig. 0.000. Chi-squared: 457,318 (gl:171).

A regression model (OLS) is proposed after these five factors that define the SDGs and the different sustainable entrepreneurships are identified. Thus, the dependent variable is the rate of business creation and the independent variables are these five factors (Table 3 ). The proposed model explains $60.4 \%$ of the total variance and its results consider two significant factors: (a) factor 1, that encompasses the social conditions and infrastructures of the regions and (b) factor 5, that brings together the elements of gender diversity and the circular economy. Both factors present a positive relationship to entrepreneurship.

Table 3. Explanatory SDG factors of entrepreneurial dynamics in Europe ${ }^{1}$.

\begin{tabular}{|c|c|c|c|c|c|c|c|}
\hline \multirow[t]{2}{*}{ Variables } & \multicolumn{2}{|c|}{$\begin{array}{l}\text { Coef. No } \\
\text { Standar. }\end{array}$} & \multirow{2}{*}{$\begin{array}{l}\text { Coef. } \\
\text { Stand. } \\
\text { Beta }\end{array}$} & \multirow[t]{2}{*}{$t$} & \multirow[t]{2}{*}{ Sig. } & \multirow[t]{2}{*}{$\mathbf{R}$} & \multirow[t]{2}{*}{$\mathbf{R}^{2}$} \\
\hline & Beta & $\begin{array}{l}\text { Desv. } \\
\text { Error }\end{array}$ & & & & & \\
\hline (Constant) & 4.962 & 3.042 & & 1.631 & 0.116 & \multirow{6}{*}{0.777} & \multirow{6}{*}{0.604} \\
\hline Social Conditions and Infrastructure & 16.540 & 4.148 & 0.512 & 3.988 & 0.001 & & \\
\hline Environment & -0.243 & -1.997 & 0.058 & -0.384 & 0.991 & & \\
\hline Social Exclusion & -0.222 & -1.040 & 0.309 & -0.212 & 0.361 & & \\
\hline Smart Cities & 0.040 & 0.305 & 0.763 & 0.063 & 0.983 & & \\
\hline Circular Economy and Gender & 13.794 & 2.993 & 0.592 & 4.608 & 0.000 & & \\
\hline
\end{tabular}

${ }^{1}$ Source: own work.

\section{Discussion}

According to previous results, the conclusions are the following:

- the emergence and promotion of the SDGs by European institutions has contributed positively to the generation of new business opportunities, contributing to a process of European regional convergence.

- The explanatory variables of the different SDGs that most contribute to explaining the creation of companies are those associated with health, social well-being, environmental protection, and the promotion of new energy sources.

- The regression analysis proposed highlights that the development of the principles of the circular economy favors the emergence of new business opportunities and the adaptation of new business models in existing companies. 
- In this sense, sustainable entrepreneurship still requires new sustainable economicproductive models associated with the primary sector (organic entrepreneurship) and the food and derivatives industry.

There are still no clear registers in a harmonized and regionalized manner that report on the typologies of enterprises (green, circular, organic, etc.). In an approximate way, it can be determined whether more opportunities have really been generated in the primary sectors, the energy sector and in the recycling industry. This is one of the main limitations of the study when measuring the new ventures that arise as an opportunity to take advantage of the philosophy of the SDGs. In an extension of the study, the variable of business creation classified by sectors will be considered. Likewise, the environmental conditions that promote greatest sustainable entrepreneurships will be developed as well.

Author Contributions: Conceptualization, M.S. methodology, F.C.; validation, M.S. and F.C.; formal analysis, F.C.; writing-review and editing, M.T.d.V. All authors have read and agreed to the published version of the manuscript.

Funding: This research received no external funding.

Institutional Review Board Statement: Not applicable.

Informed Consent Statement: Not applicable.

Data Availability Statement: Not applicable.

Conflicts of Interest: The authors declare no conflict of interest.

\section{References}

1. Schaper, M. Making Ecopreneurs: Developing Sustainable Entrepreneurship; CRC Press: London, UK; New York, NY, USA, 2016; ISBN 9780566088759.

2. Belz, F.M.; Binder, J.K. Sustainable Entrepreneurship: A Convergent Process Model. Bus. Strategy Environ. 2017, 26, 1-17. [CrossRef]

3. Ploum, L.; Blok, V.; Lans, T.; Omta, O. Toward a Validated Competence Framework for Sustainable Entrepreneurship. Organ. Environ. 2018, 31, 113-132. [CrossRef] [PubMed]

4. Muñoz, P.; Cohen, B. Sustainable Entrepreneurship Research: Taking Stock and looking ahead. Bus. Strategy Environ. 2018, 27, 300-322. [CrossRef]

5. Espina, M.; Phan, P.H.; Markman, G. Social Innovation and Sustainable Entrepreneurship; Edward Elgar Publishing: Cheltenham, UK; Northampton, MA, USA, 2018; ISBN 9781788116848.

6. European Environment Agency (EEA). Circular Economy in Europe: Developing the Knowledge Base; EEA: Luxembourg, 2016; ISSN 19778449.

7. D'Amato, D.; Droste, N.; Winkler, K.; Toppinen, A. Thinking green, circular or bio: Eliciting researchers' perspectives on a sustainable economy with Q method. J. Clean. Prod. 2019, 230, 460-476. [CrossRef]

8. Chacin, N.; Carlos, J.; Abreu Quintero, Y. Green Logistics and Circular Economics. Int. J. Good Conscienc. 2015, $10,80-91$.

9. Bocken, N.; Ritala, P.; Huotari, P. The Circular Economy: Exploring the Introduction of the Concept among S\&P 500 Firms. J. Ind. Ecol. 2017, 21, 487-490. [CrossRef]

10. Manninen, K.; Koskela, S.; Antikainen, R.; Bocken, N.; Dahlbo, H.; Aminoff, A. Do circular economy business models capture intended environmental value propositions? J. Clean. Prod. 2018, 171, 413-422. [CrossRef]

11. D'Amato, D.; Veijonaho, S.; Toppinen, A. Towards sustainability? Forest-based circular bioeconomy business models in Finnish SMEs. For. Policy Econ. 2020, 110, 101848. [CrossRef]

12. Hansen, E. Responding to the Bioeconomy: Business Model Innovation in the Forest Sector. In Environmental Impacts of Traditional and Innovative Forest-Based Bioproducts; Springer: Singapore, 2016; pp. 227-248, ISBN 9789811006531.

13. Reim, W.; Parida, V.; Sjödin, D.R. Circular Business Models for the Bio-Economy: A Review and New Directions for Future Research. Sustainability 2019, 11, 2558. [CrossRef]

14. Ariffin, S.K.; Dihanan, N.N.; Wahid, N.A. Investigating the Factors Affecting Consumer Purchase Intention towards Halal Organic Food. J. Entrep. Bus. Econ. 2019, 7, 162-188.

15. Liang, R.-D. Predicting intentions to purchase organic food: The moderating effects of organic food prices. Br. Food J. 2016, 118, 183-199. [CrossRef]

16. Kuratko, D.F. The Emergence of Entrepreneurship Education: Development, Trends, and Challenges. Entrep. Theory Pract. 2005, 29, 577-597. [CrossRef]

17. Haour, G. Israel, a powerhouse for networked entrepreneurship. Int. J. Entrep. Innov. Manag. 2005, 5, 39. [CrossRef]

18. Hope, J.B.; Mackin, P.C. Factors Affecting Entrepreneurship Among Veterans; SAG Corporation: Annandale, VA, USA, 2011. 
19. Avrahami, Y.; Lerner, M. The effect of combat service and military rank on entrepreneurial careers: The case of Israeli MBA graduates. J. Polit. Mil. Sociol. 2003, 31, 97-118.

20. Ferreira, J.J.M.; Fernandes, C.I.; Kraus, S. Entrepreneurship research: Mapping intellectual structures and research trends. Rev. Manag. Sci. 2019, 13, 181-205. [CrossRef]

21. Kannampuzha, M.; Hockerts, K. Organizational social entrepreneurship: Scale development and validation. Soc. Enterp. J. 2019, 15, 290-319. [CrossRef]

22. Terrell, K.; Troilo, M. Values and female entrepreneurship. Int. J. Gend. Entrep. 2010, 2, 260-286. [CrossRef]

23. Anna, A.L.; Chandler, G.N.; Jansen, E.; Mero, N.P. Women business owners in traditional and non-traditional industries. J. Bus. Ventur. 2000, 15, 279-303. [CrossRef]

24. Wagner, J. What a Difference a Y makes-Female and Male Nascent Entrepreneurship in Germany. Small Bus. Econ. 2007, $28,1-21$. [CrossRef]

25. Shabbir, A.; Di Gregorio, S. An examination of the relationship between women's personal goals and structural factors influencing their decision to start a business: The case of Pakistan. J. Bus. Ventur. 1996, 11, 507-529. [CrossRef]

26. Du Rietz, A.; Henrekson, M. Testing the Female Underperformance Hypothesis. Small Bus. Econ. 2000, 14, 1-10. [CrossRef]

27. Coleman, S. The Role of Human and Financial Capital in the Profitability and Growth of Women-Owned Small Firms. J. Small Bus. Manag. 2007, 45, 303-319. [CrossRef]

28. Kummitha, R.K.R. Smart cities and entrepreneurship: An agenda for future research. Technol. Forecast. Soc. Chang. 2019, 149, 119763. [CrossRef]

29. Van den Buuse, D.; Kolk, A. An exploration of smart city approaches by international ICT firms. Technol. Forecast. Soc. Chang. 2019, 142, 220-234. [CrossRef]

30. Giffinger, R.; Fertner, C.; Kramar, H.; Meijers, E. City-ranking of European medium-sized cities. Cent. Reg. Sci. Vienna UT 2007, 1-12. Available online: http:/ / www.smartcity-ranking.eu/download/city_ranking_final.pdf (accessed on 16 December 2020).

31. Meijer, A.; Bolívar, M.P.R. Governing the smart city: A review of the literature on smart urban governance. Int. Rev. Adm. Sci. 2015, 82, 392-408. [CrossRef]

32. Kummitha, R.K.R.; Crutzen, N. How do we understand smart cities? An evolutionary perspective. Cities 2017, 67, 43-52. [CrossRef] 